Received 26.03.2017 Reviewed 25.04.2017 Accepted 26.09.2017

A - study design

B - data collection

C - statistical analysis

D - data interpretation

$\mathbf{E}$ - manuscript preparation

F - literature search

\title{
Impact of land use on soils microbial activity
}

\author{
Krzysztof URBAŃSKI ${ }^{\mathrm{ABCDEF} \bowtie}$, Mateusz JAKUBIAK ${ }^{\text {ABCDEF }}$
}

AGH University of Science and Technology, Faculty of Mining Surveying and Environmental Engineering, al. Mickiewicza 30, 30-059 Kraków, Poland; e-mail: urbanski@agh.edu.pl; jakubiak@agh.edu.pl

For citation: Urbański K., Jakubiak M. 2017. Impact of land use on soils microbial activity. Journal of Water and Land Development. No. 35 p. 249-257. DOI: 10.1515/jwld-2017-0091.

\begin{abstract}
The article considered the influence the various types of land use on microbial activity of soils and thus using this parameter as a universal test of soil quality. Samples for soil respiration studies were taken from agricultural areas, meadows, forests and urban areas (estate cottages). All samples were subjected to the same analytical procedure and the method of measurement was followed by a Substrate-Induced Respiration (SIR) method. Since all the samples were from neighbouring regions and were characterized by similar soil parameters, the obtained results allowed to assess the quality of the soil environment of the surveyed area and to evaluate the total rating of whole area. The obtained results allowed to observe slight divergences between soil samples taken from areas of different use. And although statistically, in this case, these differences were not significant, the characteristics of the respiration curves clearly indicate that there is a dependency between the form of use and the size and rate of soil respiration. In addition, the results have shown that single family housing does not exhibit as much anthropopression to the soil environment as it might seem.
\end{abstract}

Key words: environmental engineering, land use, soil respiration, Substrate-Induced Respiration (SIR)

\section{INTRODUCTION}

The relative equilibrium called homeostasis characterizes relationships among all components of natural ecosystems. Homeostasis forms the stability and temporal immutability of parameters of living environment. Humans seem to be an exception that hardly subordinate their actions to the principle of environmental sustainability. Human pressure most often causes the biological imbalance of the environment [DowNES et al. 2002; GOUDIE 2013]. As a result, unfavorable environmental changes occur. In some cases, human impact on the environment is so intense that it causes a permanent modification. Emerging areas with unfavorable living values can affect the health and life of organisms that inhabit a modified environment [DURUIBE et al. 2007; JO, KOH 2004; JURKIEWICZ et al. 2004]. The facts about increasing soil, air and water pollution in urbanized areas are increasingly reported in the literature. The global impact of human pressure has the effect of reducing the natural resources of the seas and oceans, clean drinking water and natural forests [CHARLESWORTH et al. 2003; GALUŠKOVÀ 2011; MEUSER 2010; MOTYKA et al. 2005].

Appropriate planning and subsequent land use, both in macro and micro scale, can help to minimize the anthropogenic impact on the environment. The most appropriate way to achieve sustainable spatial management seems to be a balanced development of available space that includes as many natural and seminatural habitats as possible, like forests and meadows, and in urban areas - parks and other green areas. Compared with urban or industrial areas, such areas are characterized by a relatively higher biodiversity. Diversification of habitats directly affects the greater ability to immobilize, buffer, filter and transform various substances, often harmful to living organisms, including humans [GOSPODAREK et al. 2016; SCHOENHOLTZA et al. 2000]. Sustainable land management has particular impact on soils, which, due to their specificity and 
functions, can be considered the most important environmental element. Additionally, forests and meadows (or parks and other green urban areas) are characterized by relatively high water retention, which has the potential to affect local microclimates and to regulate groundwater levels [FAO 2013]. The phytosanitary influence of vegetation (trees, bushes and herbaceous plants) on the urban air and thus the reduction of deposition of pollutants into soil is another argument in favor of maintaining a high proportion of biologically active surfaces in urban space [LULEY, BOND 2002; NOWAK 2002; SCOTT et al. 1999].

Soil is one of the most complex systems occurring in the natural environment. It is a biological-chemical reactor that is capable of creating or decomposing many different substances. Therefore, the soil participates in the circulation of nutrients and their aqueous solutions throughout the whole ecosystem. These characteristics, combined with climatic conditions, fauna and flora as well as the type of land use, create a distinctive habitat characterized by specific microbial composition. Identification of the qualitative status of the soil environment seems to be possible by analyzing the soil microbial composition or its related parameters. It should be noted that the collection and analysis of any soil data always offers the opportunity to compare the effects of different land uses as well as to draw much deeper conclusions. Analyzing biomass production or the impact of a changing climate on the environment [SANCHEZ et al. 2009; TÓTH et al. 2013] or creating specialized digital maps of the developed issues [MAKO et al. 2017; MCBRATNEY et al. 2003; VÅGEN et al. 2016] may be an examples of such a conclusion.

Detailed studies of soil are usually based on many, often complex and expensive laboratory analyzes, which provide a lot of data. The testing of a single sample of soil substrate to obtain an aggregate response that determines the quality of the soil environment might be a cheaper alternative. Such a parameter, which can provide information about the degree and

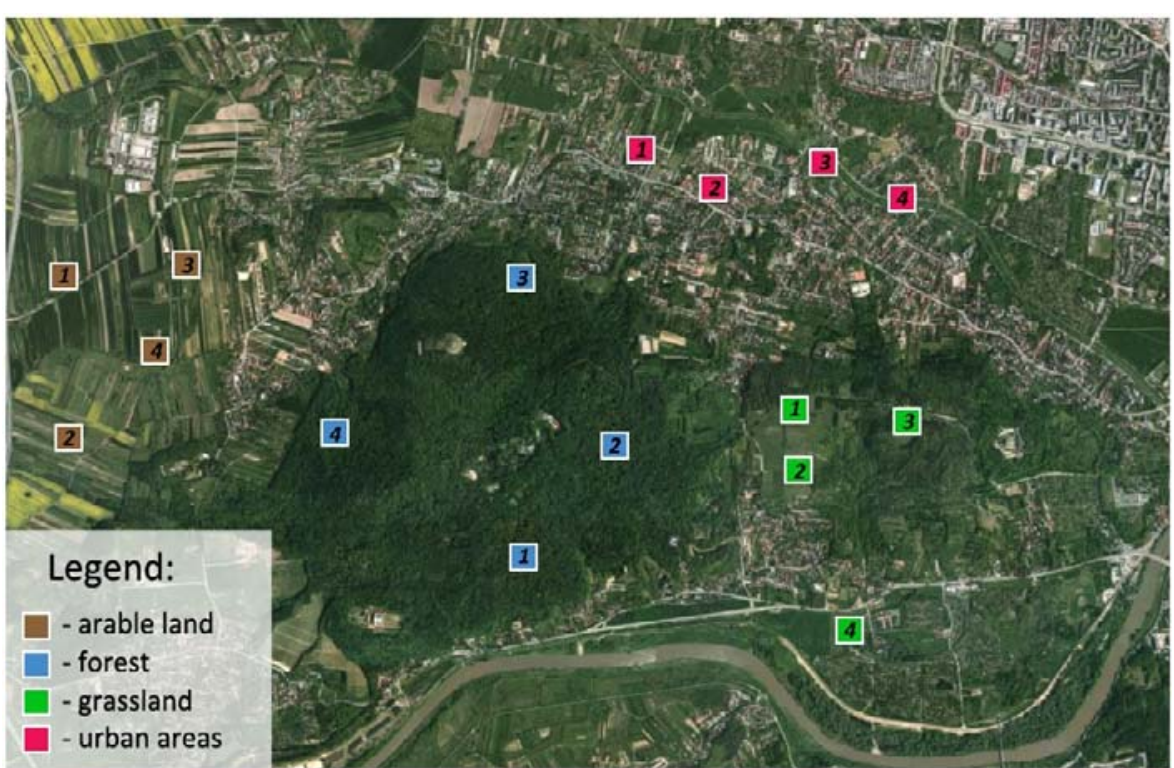

Fig. 1. Location of soil sampling points; source: own elaboration based on GoogleMaps strength of the soil transformations, can be the microbial activity. This soil parameter is strongly correlated with many other major soil properties [BALOGH et al. 2011; BURCZYK et al. 2016; HAN et al. 2007; STEFANOWICZ et al. 2008; TURBIAK et al. 2014; WANG et al. 2014]. Its value may be a determinant of the specific soil substrate - qualitative determinant of the soil environment. Thus, it allows to know the current state of the analyzed area, and it could be helpful in planning transformation of the relevant part of the soil to achieve a satisfactory effect.

The aim of this work was to confirm the possibility of influencing the various types of land use on microbial activity of soils and thus using this parameter as a universal test of soil quality. The information in such way obtained can be used in the future for example in spatial planning. In order to prove the above thesis, the analysis of soil's microbiological activity of samples taken from different land use was planned. Next the correlation between soil respiration and other soil parameters as well as land use dependence were examined.

\section{MATERIAL AND METHODS}

The study of the impact of land use on the value of soil respiration was based on soil samples collected at the research area at the end of September 2015. The area was about $6 \mathrm{~km}$ on the east from the centre of Kraków (Main Square). Samples were collected from agricultural (arable land), meadow, forest and urbanized (single family houses) areas. In total, 16 mean soil samples were collected from a depth of $0-30 \mathrm{~cm}$ (4 sampling points for each type of land use) (Fig. 1). Soil samples from forest areas were collected without the litter.

The mean samples collected from each sampling point weighed about $1 \mathrm{~kg}$. Every soil sample was divided into two parts. The first part of fresh sample was sieved through a $2 \mathrm{~mm}$ mesh, placed in a refrigerator and stored at $4^{\circ} \mathrm{C}$. Smaller samples were extracted from prepared soil material. Samples were brought to a moisture level corresponding to a $60 \%$ water field capacity and then conditioned for $48 \mathrm{~h}$ after which soil respiration was started.

Then the measurement of soil respiration were started. The Substrate-Induced Respiration (SIR) with use of glucose as substrate $\left(2000 \mu \mathrm{g} \cdot \mathrm{kg}^{-1}\right.$ DM soil) was applied as a method of microbiological activity measurement [ANDERSON, DOMSCH 1978]. The second part of 
each mean sample was dried, sieved through a sieve with a mesh diameter of $2 \mathrm{~mm}$, and then used to determine the basic soil parameters such as the granulometric composition (Casagrande method), specific density, value $\mathrm{pH}$ (in $\mathrm{H}_{2} \mathrm{O}$ and $\mathrm{KCl}$ ), electronic conductivity, carbonates content (using Scheibler apparatus) and humus content (by dry combustion at $400^{\circ} \mathrm{C}$ ).

The results were statistically analyzed with use of the Statistica software package. The hypotheses were tested using the analysis of variance (ANOVA), the Tukey test, and the Kruskal-Wallis test. The confidence level of all tests was $0.05(\alpha=0.05)$.

\section{RESULTS AND DISCUSSION}

The granulometric composition of all soil samples was very similar (Fig. 2a, b). Soils with a dominant fraction of silt prevailed. The average content of silt was over $77 \%$. The highest content of silt parts was found in soil samples from meadow areas and the lowest in urban areas. Urban areas were characterized by the highest content of sand fraction, which in samples taken from other types of land use was significantly lower. The average content of sand fraction in all samples was almost $15 \%$. In urbanized areas the average was of $25 \%$ whereas for agricultural, forestry and meadow areas it was around $10 \%$ (Tab. 1). The average content of the clay fraction was very low and did not exceed $10 \%$ in all cases of land use.

Despite slight differences in the granulometric composition of individual samples from different land uses only the fraction of sand could be recorded as statistically significant and only at the significance level $\alpha=0.10$, which was twice as high as originally assumed.

In case of other tested soil characteristics situation was similar. The tests did not show significant differences between soil samples from different areas of use. Only the soil reaction in urbanized areas and forests showed significant variation. By increasing the alpha significance level to 0.10 , statistically significant differences also showed in case of the soil density and soil reaction (comparing agricultural and forests areas) and the carbonate content (comparing urban areas and all other land uses). In many studies, a value of $\alpha=0.05$ is generally regarded as a limit of acceptable error rate and increasing it to 0.10 is not justified. The higher level of $\alpha$ means the lower reliability of the tested relationship between respective variables [MANLY 2008].

a)

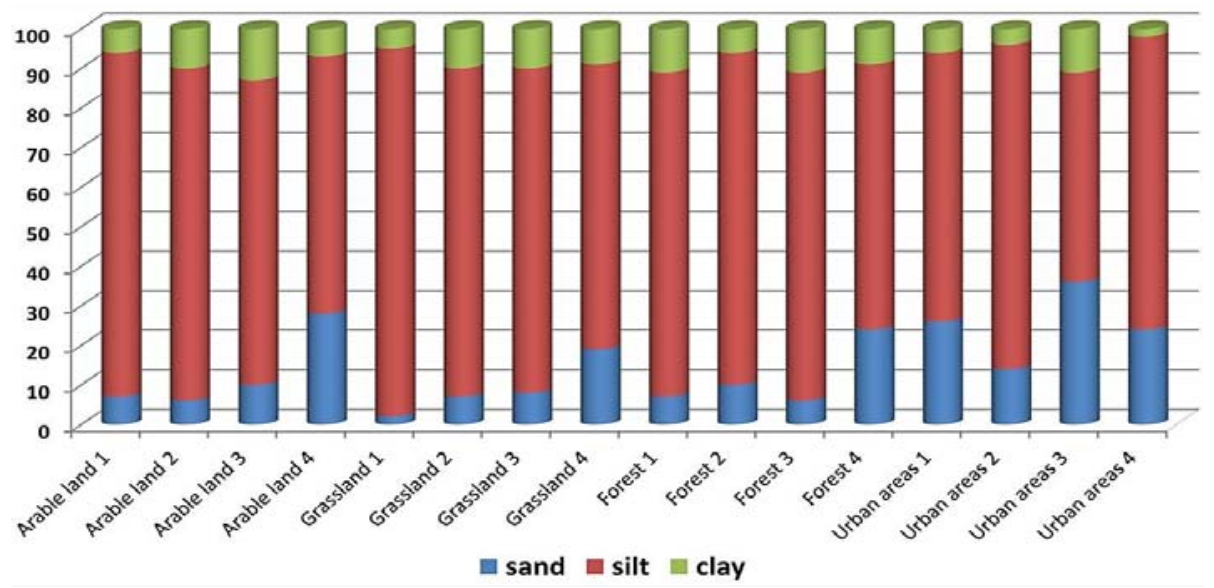

b)

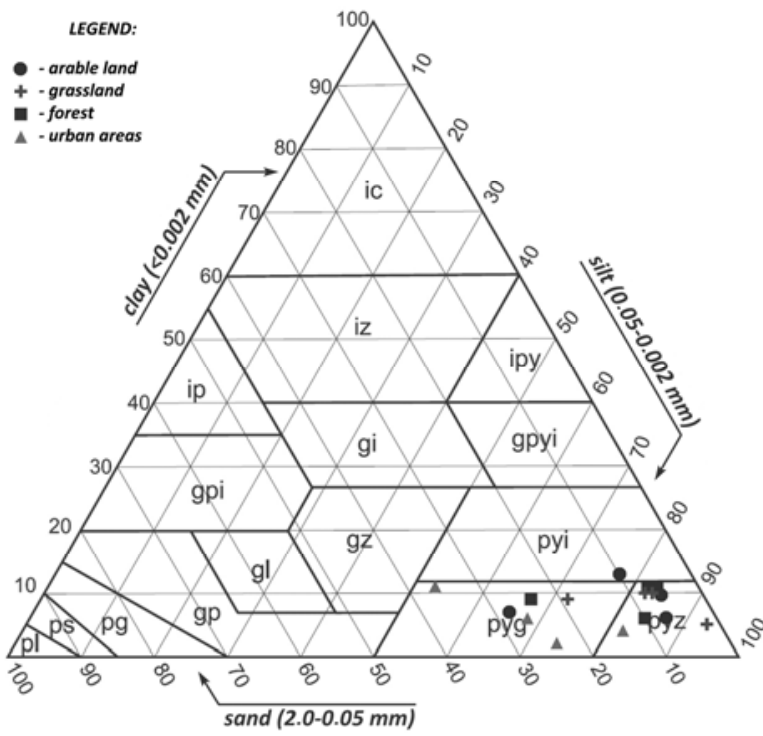

Fig. 2. Grain size distribution of soil samples; source: according to the PTG [2009] and the FAO/WBR classification 
Table. 1. Basic statistics of analyzed soil parameters

\begin{tabular}{|c|c|c|c|c|c|c|}
\hline Parameter & Unit & 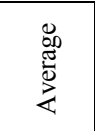 & 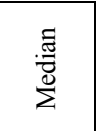 & 声 & $\begin{array}{l}\text { 目 } \\
\text { 咅 } \\
\text { 旁 }\end{array}$ & 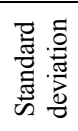 \\
\hline \multicolumn{7}{|c|}{ All cover land } \\
\hline Sand & $\%$ & 14.63 & 10.00 & 2.00 & 36.00 & 10.10 \\
\hline Silt & $\%$ & 77.25 & 82.00 & 53.00 & 93.00 & 10.12 \\
\hline Clay & $\%$ & 8.13 & 9.00 & 2.00 & 13.00 & 3.05 \\
\hline Soil density & $\mathrm{g} \cdot \mathrm{cm}^{-3}$ & 2.57 & 2.57 & 2.43 & 2.64 & 0.05 \\
\hline pH KCl & - & 5.28 & 5.50 & 3.30 & 7.00 & 1.17 \\
\hline $\mathrm{pH} \mathrm{H}_{2} \mathrm{O}$ & - & 5.91 & 6.10 & 4.10 & 7.30 & 0.92 \\
\hline$E C$ & $\mu \mathrm{S} \cdot \mathrm{cm}^{-1}$ & 119.79 & 117.60 & 56.10 & 214.00 & 44.57 \\
\hline $\mathrm{CaCO}_{3}$ & $\%$ & 0.31 & 0.00 & 0.00 & 2.64 & 0.68 \\
\hline $\mathrm{OM}$ & $\%$ & 1.93 & 1.90 & 1.50 & 2.40 & 0.27 \\
\hline \multicolumn{7}{|c|}{ Arable land } \\
\hline Sand & $\%$ & 12.75 & 8.50 & 6.00 & 28.00 & 10.31 \\
\hline Silt & $\%$ & 78.25 & 80.50 & 65.00 & 87.00 & 9.78 \\
\hline Clay & $\%$ & 9.00 & 8.50 & 6.00 & 13.00 & 3.16 \\
\hline Soli density & $\mathrm{g} \cdot \mathrm{cm}^{-3}$ & 2.60 & 2.60 & 2.57 & 2.64 & 0.03 \\
\hline $\mathrm{pH} \mathrm{KCl}$ & - & 4.93 & 4.95 & 4.20 & 5.60 & 0.64 \\
\hline $\mathrm{pH} \mathrm{H}_{2} \mathrm{O}$ & - & 5.88 & 5.90 & 5.40 & 6.30 & 0.38 \\
\hline$E C$ & $\mu \mathrm{S} \cdot \mathrm{cm}^{-1}$ & 84.88 & 68.55 & 56.10 & 146.30 & 41.37 \\
\hline $\mathrm{CaCO}_{3}$ & $\%$ & 0.06 & 0.05 & 0.00 & 0.15 & 0.08 \\
\hline $\mathrm{OM}$ & $\%$ & 1.80 & 1.80 & 1.58 & 2.00 & 0.19 \\
\hline \multicolumn{7}{|c|}{ Grassland } \\
\hline Sand & $\%$ & 9.00 & 7.50 & 2.00 & 19.00 & 7.16 \\
\hline Silt & $\%$ & 82.50 & 82.50 & 72.00 & 93.00 & 8.58 \\
\hline Clay & $\%$ & 8.50 & 9.50 & 5.00 & 10.00 & 2.38 \\
\hline Soli density & $\mathrm{g} \cdot \mathrm{cm}^{-3}$ & 2.57 & 2.57 & 2.54 & 2.60 & 0.02 \\
\hline $\mathrm{pH} \mathrm{KCl}$ & - & 5.70 & 6.00 & 4.30 & 6.50 & 0.97 \\
\hline $\mathrm{pH} \mathrm{H}_{2} \mathrm{O}$ & - & 6.28 & 6.45 & 5.50 & 6.70 & 0.53 \\
\hline$E C$ & $\mu \mathrm{S} \cdot \mathrm{cm}^{-1}$ & 130.78 & 118.10 & 93.90 & 193.00 & 43.03 \\
\hline $\mathrm{CaCO}_{3}$ & $\%$ & 0.05 & 0.00 & 0.00 & 0.19 & 0.10 \\
\hline $\mathrm{OM}$ & $\%$ & 2.05 & 2.05 & 1.80 & 2.30 & 0.21 \\
\hline \multicolumn{7}{|c|}{ Forest } \\
\hline Sand & $\%$ & 11.75 & 8.50 & 6.00 & 24.00 & 8.34 \\
\hline Silt & $\%$ & 79.00 & 82.50 & 67.00 & 84.00 & 8.04 \\
\hline Clay & $\%$ & 9.25 & 10.00 & 6.00 & 11.00 & 2.36 \\
\hline Soli density & $\mathrm{g} \cdot \mathrm{cm}^{-3}$ & 2.51 & 2.51 & 2.43 & 2.61 & 0.08 \\
\hline $\mathrm{pH} \mathrm{KCl}$ & - & 4.03 & 3.70 & 3.30 & 5.40 & 0.94 \\
\hline $\mathrm{pH} \mathrm{H}_{2} \mathrm{O}$ & - & 4.73 & 4.50 & 4.10 & 5.80 & 0.76 \\
\hline$E C$ & $\mu \mathrm{S} \cdot \mathrm{cm}^{-1}$ & 116.23 & 117.45 & 77.70 & 152.30 & 32.72 \\
\hline $\mathrm{CaCO}_{3}$ & $\%$ & 0.00 & 0.00 & 0.00 & 0.00 & 0.00 \\
\hline $\mathrm{OM}$ & $\%$ & 2.18 & 2.25 & 1.80 & 2.40 & 0.26 \\
\hline \multicolumn{7}{|c|}{ Urban areas } \\
\hline Sand & $\%$ & 25.00 & 25.00 & 14.00 & 36.00 & 9.02 \\
\hline Silt & $\%$ & 69.25 & 71.00 & 53.00 & 82.00 & 12.26 \\
\hline Clay & $\%$ & 5.75 & 5.00 & 2.00 & 11.00 & 3.86 \\
\hline Soli density & $\mathrm{g} \cdot \mathrm{cm}^{-3}$ & 2.59 & 2.59 & 2.56 & 2.63 & 0.03 \\
\hline $\mathrm{pH} \mathrm{KCl}$ & - & 6.45 & 6.50 & 5.80 & 7.00 & 0.49 \\
\hline $\mathrm{pH} \mathrm{H}_{2} \mathrm{O}$ & - & 6.78 & 6.80 & 6.20 & 7.30 & 0.45 \\
\hline$E C$ & $\mu \mathrm{S} \cdot \mathrm{cm}^{-1}$ & 147.30 & 136.75 & 101.70 & 214.00 & 49.85 \\
\hline $\mathrm{CaCO}_{3}$ & $\%$ & 1.12 & 0.80 & 0.22 & 2.64 & 1.06 \\
\hline $\mathrm{OM}$ & $\%$ & 1.70 & 1.70 & 1.50 & 1.90 & 0.18 \\
\hline
\end{tabular}

Explanations: $E C=$ electrical conductivity, $\mathrm{OM}=$ organic matter. Source: own study.

The mean values of specific density were 2.57 $\mathrm{g} \cdot \mathrm{cm}^{-3}$ and the lowest values were noted in the forest areas (Tab. 1) while the highest in the agricultural land. The forest areas also had the lowest mean values of the other tested parameters: $\mathrm{pH}$ level, salinity and car- bonate content, which in soil samples from the forest were not found at all. The highest average values for these features were recorded for soil samples from urbanized areas (Tab. 1). Increased salt content in urbanized areas may be result from the use of salts for road deicing [CHUDECKA 2010; JAKUBIAK, URBAŃSKI 2015; KoCHANOWSKA, KUSZA 2012]. The crushed rock fragments, which along with the construction work was moved closer to the surface of the soil, or the deposition of alkaline ashes from domestic fireplaces into home gardens might have affected the higher $\mathrm{pH}$.

Analysis of the results from the soil respiration test showed high similarities between samples from different land uses. In each case the growth of carbon dioxide cumulation was almost identical. A rapid increase in $\mathrm{CO}_{2}$ production (rapid respiration) was observed approximately until $24^{\text {th }} \mathrm{h}$ of study. After that the soil respiration slowed down (Fig. 3). The most rapid changes in this process have been observed for urbanized areas. The curve in $24 \mathrm{~h}$ period is clearly going down. The mildest form take cumulative respiration charts for forest areas. A better illustration of this phenomenon are the graphs of successive $\mathrm{CO}_{2}$ increments for particular areas where the characteristic peaks can be observed (Fig. 4).

Similarly, for urban areas, the climax around the $15^{\text {th }} \mathrm{h}$ of the study is very clear. While, for forest areas, only a small bulge of the chart in this place was visible. Forestland samples were characterized by the greatest uniformity of $\mathrm{CO}_{2}$ increments during the measurement period as well as the smallest fluctuations between successive readings of carbon dioxide concentration. Comparison of cumulative respiration graphs and successive increments graphs (Fig. 3a, 4) allowed to observe other differences. For urbanized and forested areas the curves for all four samples were cumulated in a small range. It shows the high similarity between the individual samples in the group. However, for agricultural land and meadows, the distribution of curves on the graph was much higher. Most likely, it was due to the higher diversity of soil characteristics between the individual samples.

Comparing the maximum values obtained for the 72-hour period, it turned out that the agricultural land had the highest average respiration (over $6,000 \mathrm{ppm}$ $\mathrm{CO}_{2}$ ). Meadows were on the next place $(5,918 \mathrm{ppm})$, then urbanized areas $(5,758 \mathrm{ppm})$ and forests $(5,544$ ppm) (Tab. 2, Fig. 5).

Table. 2. Respiration rate in a specified time interval for different land use patterns

\begin{tabular}{|l|c|c|c|}
\hline \multirow{2}{*}{\multicolumn{1}{c|}{ Land use }} & \multicolumn{3}{|c|}{ Mean value, ppm } \\
\cline { 2 - 4 } & $24 \mathrm{~h}$ & $48 \mathrm{~h}$ & $72 \mathrm{~h}$ \\
\hline All & 3252 & 5122 & 5997 \\
\hline Arable land & 2906 & 5179 & 6037 \\
\hline Grassland & 3584 & 5004 & 5918 \\
\hline Forest & 2954 & 4744 & 5544 \\
\hline Urban areas & 3747 & 5116 & 5758 \\
\hline
\end{tabular}

Source: own study. 
This trend was not retained throughout the whole respiration measurement period. In the first hours of measurements, samples from urbanized areas received the highest values of cumulative $\mathrm{CO}_{2}$. After $24 \mathrm{~h}$ the value was over 3700 ppm. For comparison, the same reading for farmland samples showed the value of 2900 ppm (Tab. 2, Fig. 5). During the first $24 \mathrm{~h}$ of the study, also the soil from the meadows had relatively high level of respiration (compared to other samples). The level of respiration after $24 \mathrm{~h}$ was almost 3600 ppm of accumulated $\mathrm{CO}_{2}$. However, the further study of these samples showed a slowdown of soil respiration. After next $24 \mathrm{~h}$ the measured value was about 5000 ppm (Tab. 2, Fig. 5).

Despite the observed differences in total soil respiration in a period of $72 \mathrm{~h}$, the statistical tests conducted did not confirm their significance. All the analyzed soil respiration distributions for individual samples were also characterized by very high correlation, which further confirms the high similarity between the soil samples of the examined forms of land use. Slight differences in soil respiration probably resulted from the small differences of the physico-chemical properties of soil samples. Therefore, the obtained results do not allow to confirm unequivocally the thesis of the influence of different land use on microbiological activity parameter and using this parameter as a universal test of soil quality. However, this assumption cannot be rejected. The study has shown that even a small difference in soil parameters between samples as well as type of land use directly affect the value of soil respiration. Examined urbanized areas were represented by single family housing estates. Pro- a)

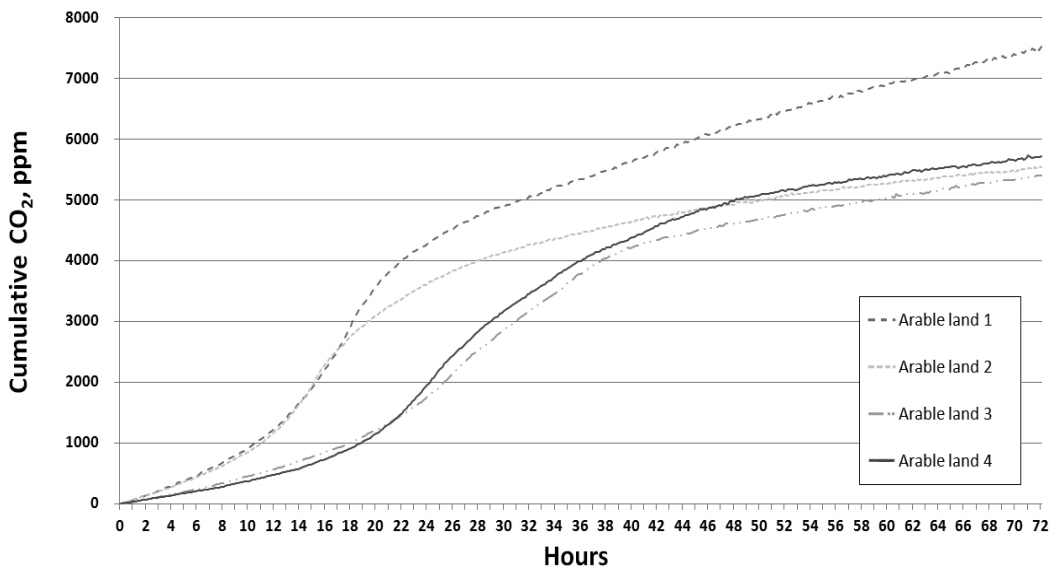

b)

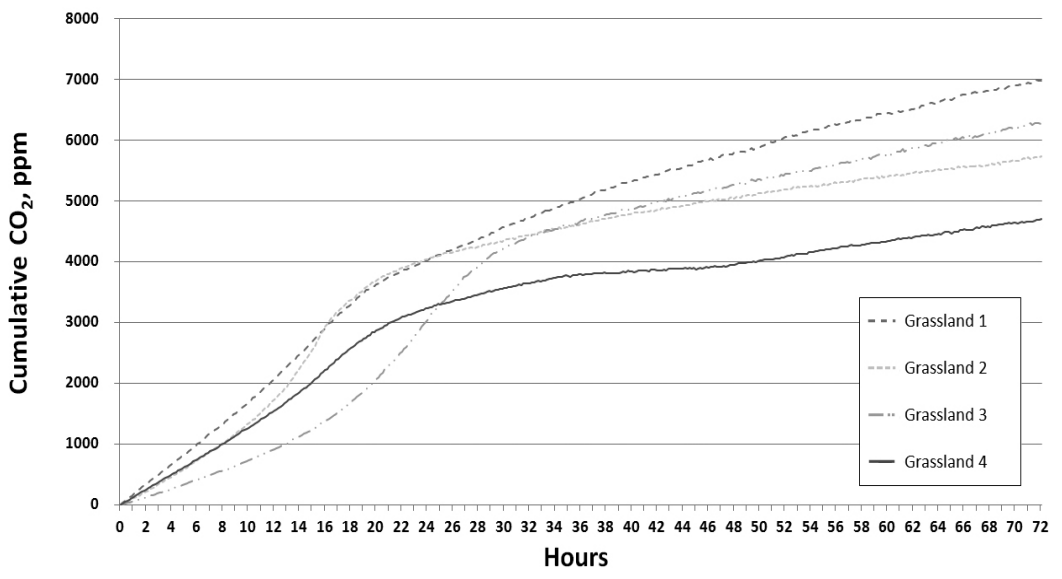

c)

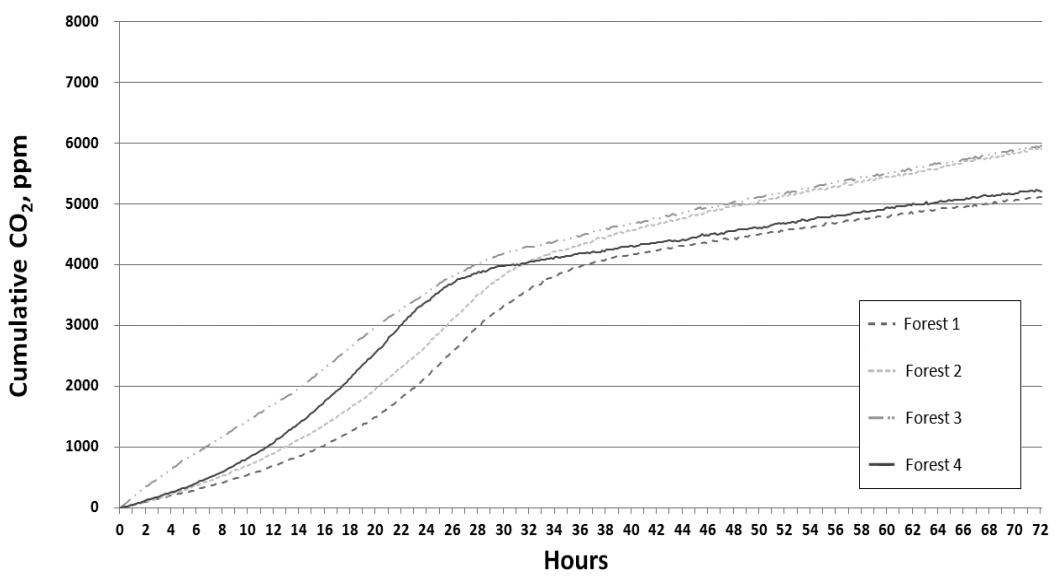

d)

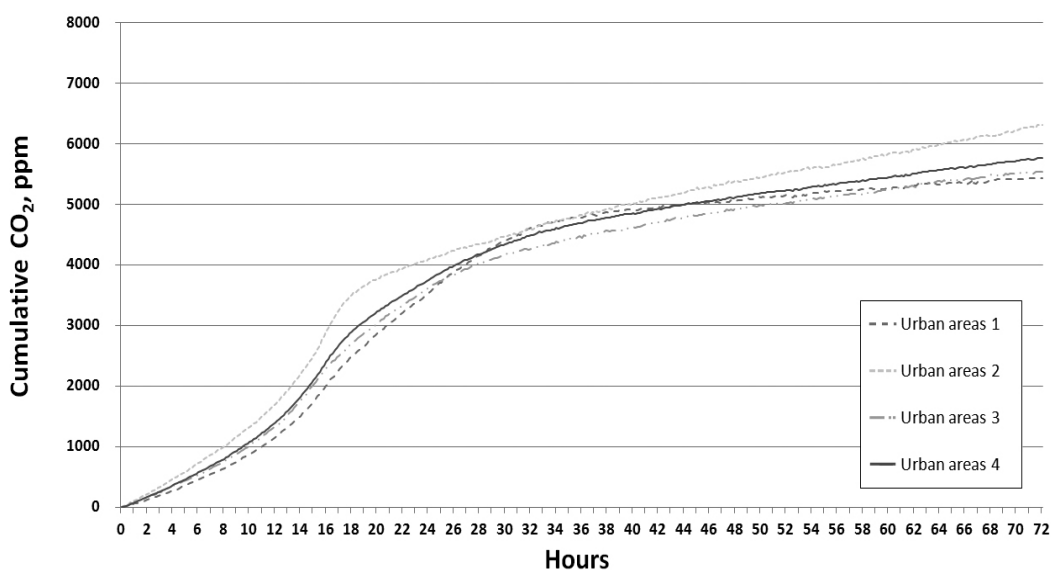

Fig. 3. Soil respiration diagrams for soil samples from different forms of land use: a) arable land, b) grassland, c) forest, d) urban areas; source: own study 
a)

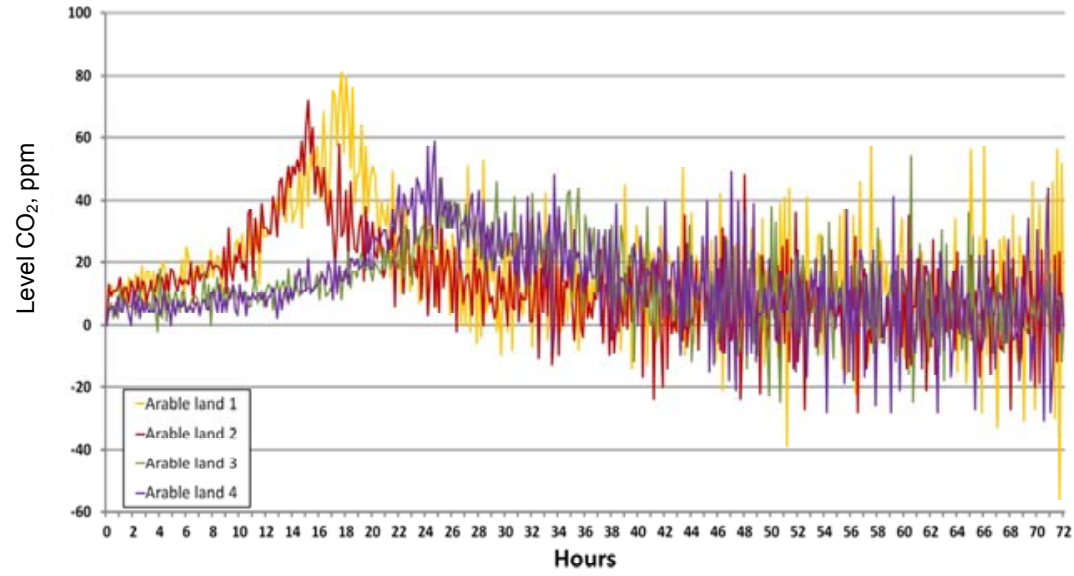

b)

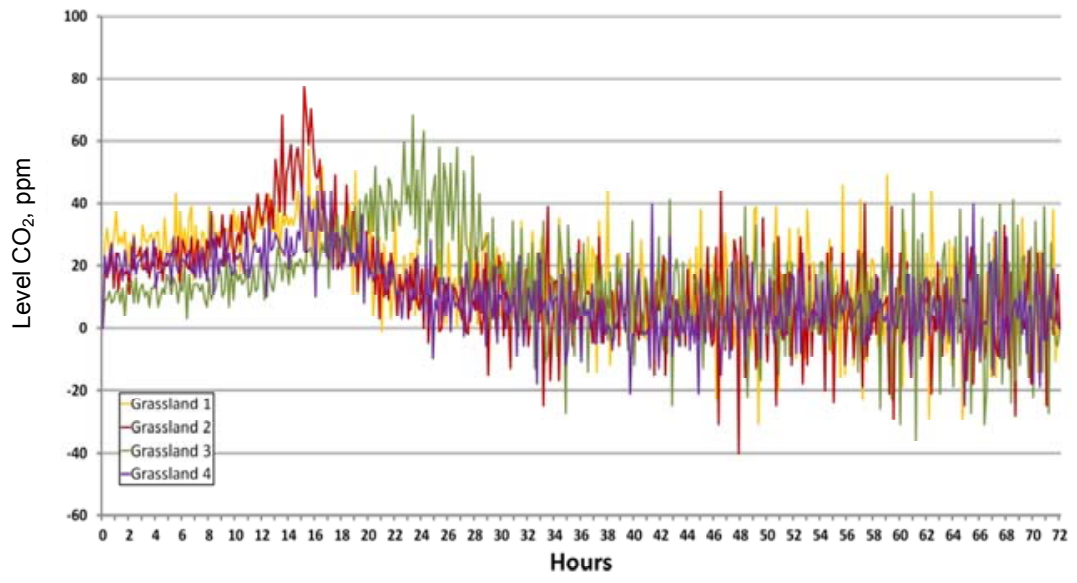

c)

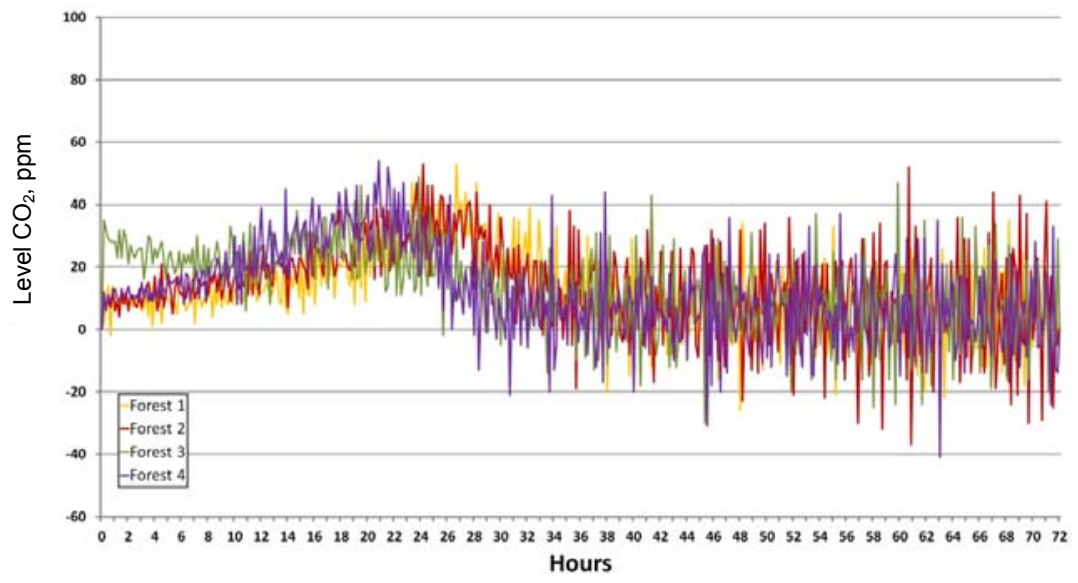

d)

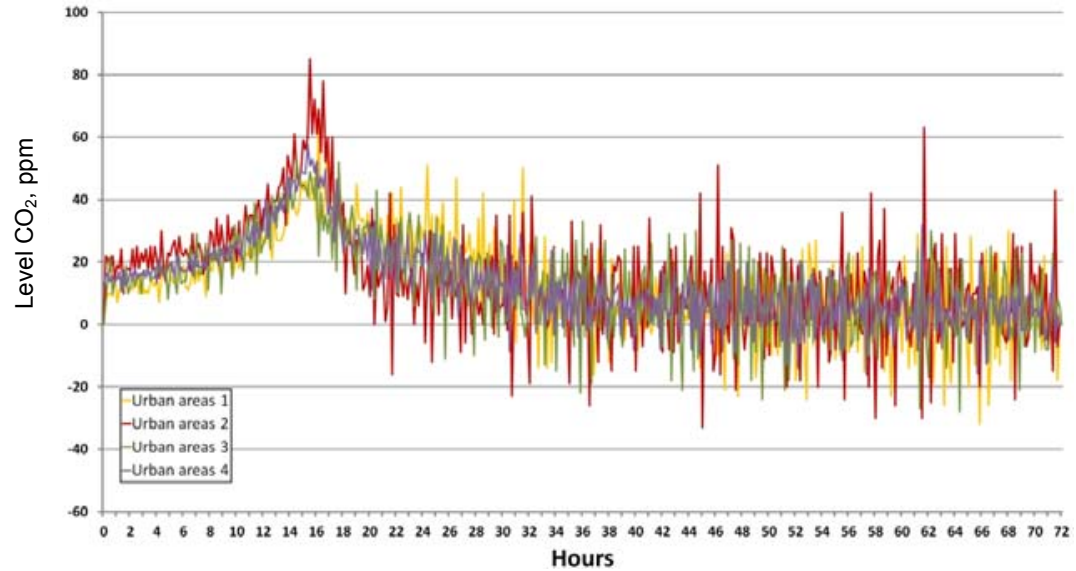

Fig. 4. Increases $\mathrm{CO}_{2}$ in time between next measurements in different forms of land use: a) arable land, b) grassland, c) forest, d) urban areas; source: own study bably the degree of anthropogenic transformation of these areas was so small that the study did not show significant differences between them and the other tested land use types. In addition, samples from urban areas were taken from residential lawn, what could also affect the similarity in respiration values comparing urban areas and meadows.

\section{CONCLUSIONS}

The possibility of using soil respiration (one of the parameters determining the microbial activity of the soil) was considered in the article as a supporting parameter in the evaluation of soil quality. The measurements allowed to observe slight discrepancies between the soil samples taken from sites with different land use. Although the differences were not statistically significant, the characteristic curves of respiration clearly show a relationship between form of land use and the size and rate of respiration of soil. Perhaps, the expected large influence of urban areas anthropopression on the soil environment was not observed in a satisfactory scale. However, this impact was not completely excluded. On the contrary, the results indicate the need for further, more detailed study of this issue. It can be assumed that the variation in soil respiration rate could be higher in some cases, eg. when urban areas are developed as multifamily housing estate, industrial areas or even when soil samples would be collected from a greater variety of urban areas. In case of the conducted research, the urban areas were represented by a single family housing estate. The results of the respirations did not differ significantly from other forms of land use such 
a)

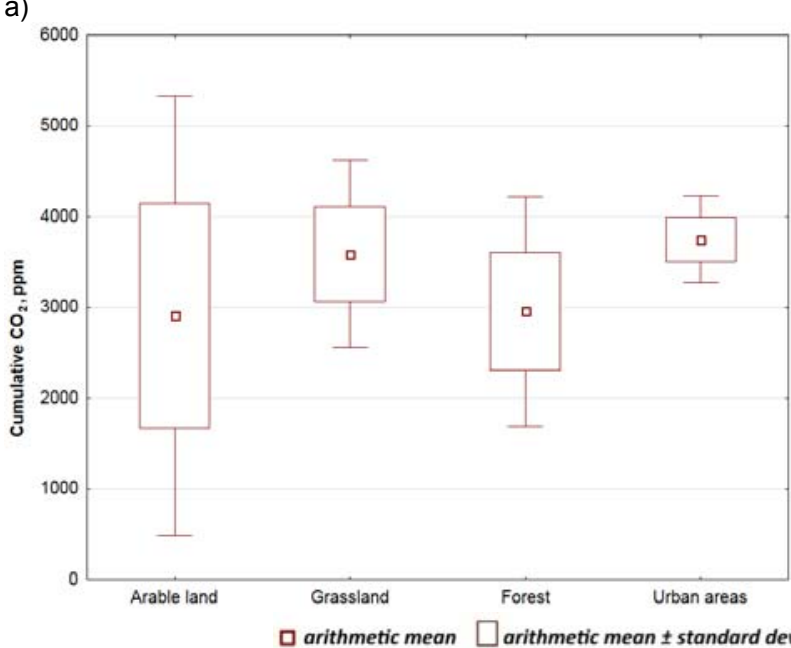

b)

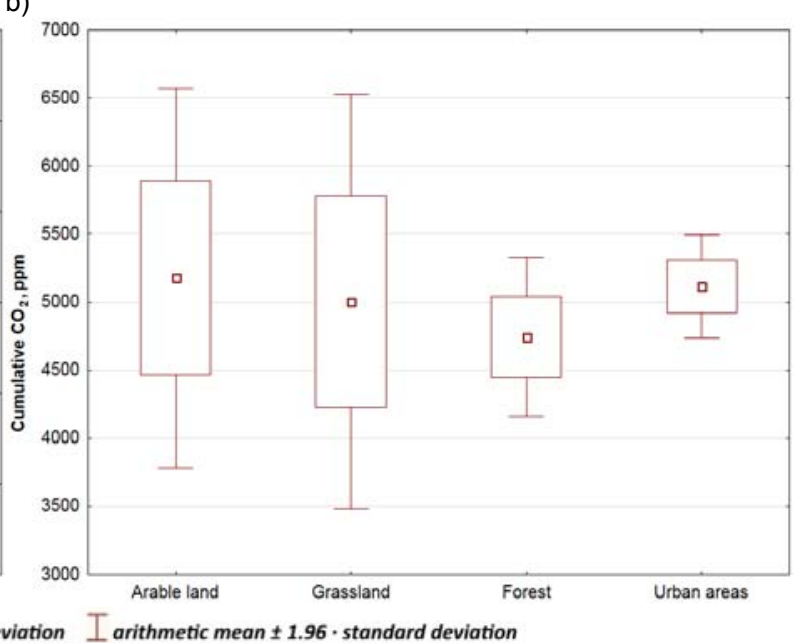

c)

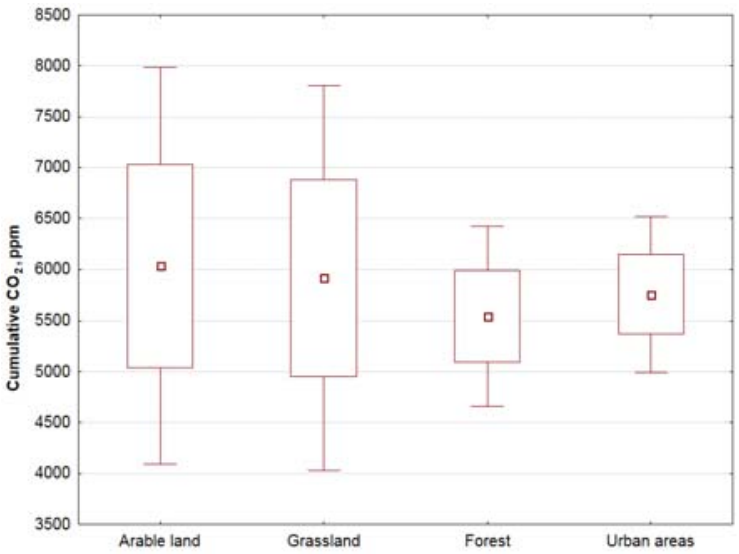

d)

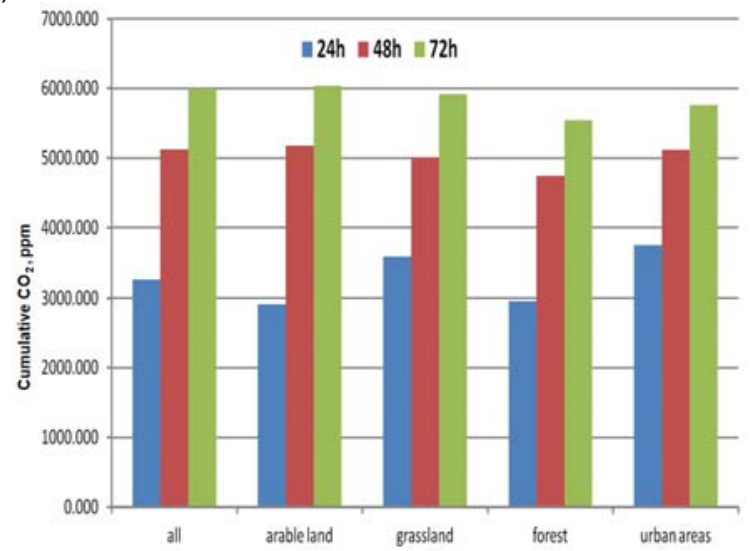

Fig. 5. Changes in mean soil respiration after specific time intervals for different land use patterns: a) after $24 \mathrm{~h}$, b) after $48 \mathrm{~h}, \mathrm{c}$ ) after $72 \mathrm{~h}, \mathrm{~d}$ ) mean values; source: own study

as forest, arable land or meadows. It allowed to conclude that such sites are very similar in terms of microbial activity of soils. Thus, at least theoretically, these sites could be considered as areas that positively affect the overall balance of biochemical changes occurring in the soil environment and favourably affect biological balance, the balance, which is the basis for the ability to immobilize, buffer, filter, and transform various substances into the soil environment.

\section{Acknowledgement}

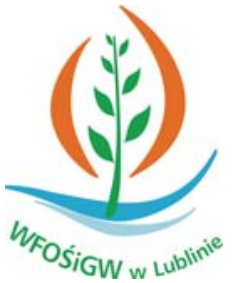

Dofinansowano ze środków

Wojewódzkiego Funduszu

Ochrony Środowiska

i Gospodarki Wodnej w Lublinie

Cofinanced by Voivodeship Fund

for Environmental Protection

and Water Management in Lublin

\section{REFERENCES}

ANDERSON J.P.E., DOMSCH K.H. 1978. A physiological method for quantitative measurement of microbial biomass in soil. Soil Biology and Biochemistry. Vol. 10 p. 215-221.
Balogh J., Pintér K., Fóti S., Cserhalmi D., Papp M., NAGY Z. 2011. Dependence of soil respiration on soil moisture, clay content, soil organic matter, and $\mathrm{CO}_{2}$ uptake in dry grasslands. Soil Biology and Biochemistry. Vol. 43 p. 1006-1013.

BurczyK P., Galczyńska M., Michalcewicz W., GamRAT R. 2016. Wpływ rodzaju nawożenia azotowego na zawartość biomasy żywych mikroorganizmów w glebie i emisję ditlenku węgla [Effect of nitrogen fertilization types on the soil microorganisms biomass and emissions of carbon dioxide]. Woda-Środowisko-Obszary Wiejskie. T. 16. Z. 2(54) p. 5-15.

Charlesworth S., Everett M., McCarthy R., Ordonez A., Miguel E. 2003. A comparative study of heavy metal concentration and distribution in deposited street dusts in a large and small urban area: Birmingham and Coventry, West Midlands, UK. Environment International. Vol. 29 p. 563-573.

Chudecka J., Tomaszewicz T., Pacewicz K., Wróbel M. 2010. Wybrane właściwości chemiczne powierzchniowej warstwy gruntów przydrożnych w okresie wiosny $\mathrm{i}$ jesieni [The chosen chemical properties of surface layer of roadside grounds in spring and autumn periods]. Folia Pomeranae Universitatis Technologiae Stetinensis. Vol. 278(14) p. 49-56.

Downes B.J., Barmuta L.A., Fairweather P.G., Faith D.P., KeOUgh M.J., LaKe P.S., Mapstone B.D., QuinN G.P. 2002. Monitoring ecological impacts. Cambridge, 
UK. Cambridge University Press. ISBN 0521771579 pp. 446.

Duruibe J.O., OGwuegbu M.O.C., Egwurugwu J.N. 2007. Heavy metal pollution and human biotoxic effects [online]. International Journal of Physical Sciences. Vol. 2(5) p. 112-118. [Access 02.02.2017]. Available at: http://www.academicjournals.org/IJPS

FAO 2013. Forests and water: international momentum and action [online]. [Access 02.02.2017]. Available at: http://www.fao.org/docrep/017/i3129e/i3129e.pdf

GALUŠKOVÀ I. 2011. Urban soil contamination by potentially risk elements. Soil \& Water Research. Vol. 6(2) p. 55-60.

Gospodarek J., Petryszak P., Kołoczek H. 2016. The effect of the bioremediation of soil contaminated with petroleum derivatives on the occurrence of epigeic and edaphic fauna. Bioremediation Journal. Vol. 20. Iss. 1 p. $38-53$.

GOUDIE A.S. 2013. The human impact on the natural environment: Past, present, and future. John Wiley and Sons Ltd. ISBN 9781118578254 pp. 424.

Han G., Zhou G., Xu Z., Yang Y., LiU J., Shi K. 2007. Biotic and abiotic factors controlling the spatial and temporal variation of soil respiration in an agricultural ecosystem. Soil Biology and Biochemistry. Vol. 39 p. $418-425$.

JAKUBIAK M., URBAŃSKI K. 2015. Impact and range assessment of anthropogenic salinity in the vicinity of communication routes on the example of national road no. 79 in Krakow. Logistyka. Nr 4 dod.: CD nr 3, Logistyka-nauka: artykuły recenzowane p. 8997-9004.

Jo I.S., Кон M.H.. 2004. Chemical changes in agricultural soils of Korea: data review and suggested countermeasures. Environmental Geochemistry and Health. Vol. 26 p. $105-117$

Jurkiewicz A., WiechuŁa D., NowaK R., GaźDZIK T., LOSKA K. 2004. Metal content in femoral head spongious bone of people living in regions of different degrees of environmental pollution in Southern and Middle Poland. Ecotoxicology and Environmental Safety. Vol. 59. Iss. 1 p. 95-101.

KochANOWSKA K., KusZA G. 2012. Wpływ zasolenia na właściwości fizyko-chemiczne gleb Opola w latach 1994 i 2009 [Healthand hazards of roadside trees in the central of Opole]. Inżynieria Ekologiczna. $\mathrm{Nr} 23$ p. 14-21.

LULEY C.J., BOND J. 2002. A plan to integrate management of urban trees into air quality planning. Report to Northeast State Foresters Association [online]. Kent. Davey Resource Group. [Access 02.02.2017]. Available at: http://urbantrees.org/policymakers/studies/ IntegrateTrees_LuleyBond.pdf

Mako A., Kocsis M., BARnA GY., TÓTH G. 2017. Mapping the storing and filtering capacity of European soils; EUR 28392 [online]. DOI 10.2788/49218. [Access 02.02.2017]. Available at: http://publications.jrc.ec. europa.eu/repository/bitstream/JRC105121/lb-na28392-en-n .pdf

MANLY B.F.J. 2008. Statistics for environmental science and management. $2^{\text {nd }}$ ed. London. CRC Press. ISBN 978-1420061475 pp. 310.
McBratney A.B., Mendonç S.M.L., Minasny B. 2003. On digital soil mapping. Geoderma. Vol. 117 p. 3-52.

MEUSER H. 2010. Causes of soil contamination in the urban environment. In: Contaminated urban soils. Ser. Environmental Pollution. Vol. 18. Dordrecht. Springer p. 29-94.

MOTYKA J., ADAmCZYK Z., CZOP M., D’OBRyn K. 2005. Wpływ składowiska odpadów komunalnych w Ujkowie koło Olkusza na jakość wód podziemnych [Groundwater quality impact by municipal sanitary landfill in Ujków near Olkusz (S Poland)]. Gospodarka Surowcami Mineralnymi. Vol. 21. Iss. 1 p. 131-153.

NowAK D.J. 2002. The effects of urban trees on air quality. Syracuse. USDA Forest Service pp. 5.

PTG 2009. Klasyfikacja uziarnienia gleb i utworów mineralnych. Roczniki Gleboznawcze. T. 60. Nr 2 p. 5-16.

Sanchez P.A., Ahamed S., Carré F., Hartemink A.E., Hempel J., Huising J., Lagacherie P., McBratney A.B., McKenzie N.J., De Lourdes M., MendonçASANTOS M.L. 2009. Digital soil map of the world. Science. Vol. 325. No. 5941 p. 680-681.

Schoenholtza S.H., Van Miegroetb H., Burger J.A. 2000. A review of chemical and physical properties as indicators of forest soil quality: Challenges and opportunities. Forest Ecology and Management. Vol. 138 p. $335-356$.

SCOTT K.I., Simpson J.R., MCPHERSON E.G. 1999. Effects of tree cover on parking lot microclimate and vehicle emissions. Journal of Arboriculture. Vol. 25(3) p. 129142.

Sokolowska Z., Matyka-SARZyŃSKa D., DĄBEK-SZReNIAWSKA M., WYCZÓ£KOWSKI A. 2004. Zależność pomiędzy niektórymi właściwościami powierzchniowymi i fizyko-chemicznymi utworów murszowych a procesami oddechowymi drobnoustrojów glebowych [Relationships between some surface and physico-chemical properties and respiration activity of microorganisms of peaty-muck soils]. Acta Agrophysica. Vol. 3 p. 593 601.

Stefanowicz A.M., NikLinska M., LASKOwSKi R. 2008. Metals affect soil bacterial and fungal functional diversity differently. Environmental Toxicology Chemistry. Vol. 27 p. 591-598.

Tóth G., Jones A., Montanarella L. 2013. The LUCAS topsoil database and derived information on the regional variability of cropland topsoil properties in the European Union. Environmental Monitoring and Assessment. Vol. 185. No. 9 p. 7409-7425.

Turbiak J., MiatKowski Z., Bolewski T. 2014. Wpływ warunków wodnych na aktywność respiracyjną gleb pobagiennych bez pokrywy roślinnej [Effect of water conditions on respiration activity of post-bog soils under the conditions of plant cover back]. Woda-ŚrodowiskoObszary Wiejskie. T. 14. Z. 4(48) p. 123-134.

VÅGEn T.-G., WinOwiecki L.A., TondoH J.E., Desta L.T., GUMBRICHT T. 2016. Mapping of soil properties and land degradation risk in Africa using MODIS reflectance. Geoderma. Vol. 263 p. 216-225.

WANG B., Zha T.S., JiA X., Wu B., Zhang Q., QIN S.G. 2014. Soil moisture modifies the response of soil respiration to temperature in dessert shrub ecosystems. Biogeosciences. Vol. 11 p. 259-268. 


\section{Krzysztof URBAŃSKI, Mateusz JAKUBIAK}

\section{Wpływ użytkowania terenu na aktywność mikrobiologiczną gleb}

\section{STRESZCZENIE}

W artykule rozpatrywano wpływ różnego rodzaju użytkowania terenu na aktywność mikrobiologiczną gleb i tym samym możliwość wykorzystania tego parametru jako uniwersalnego testu jakości podłoża glebowego. Do badań respiracji glebowej wykorzystano próbki pobrane z terenów użytkowanych rolniczo, łąk, lasów oraz terenów zurbanizowanych (zabudowa domków jednorodzinnych). Wszystkie próbki poddano identycznej procedurze analitycznej, a jako metodę pomiaru zastosowano metodę indukowanej substratem respiracji (ang. SIR - Substrate-Induced Respiration). Ponieważ wszystkie próbki pochodziły z sąsiadujących ze sobą rejonów i charakteryzowały się podobnymi parametrami glebowymi, uzyskane wyniki umożliwiły ocenę jakości środowiska glebowego badanego terenu i dokonanie oceny sumarycznej rejonu badań. Uzyskane wyniki pozwoliły zaobserwować niewielkie rozbieżności między próbkami glebowymi pobranymi z terenów o różnej formie użytkowania. Statystycznie różnice te nie były istotne, jednak na podstawie charakterystyki krzywych respiracji jednoznacznie można stwierdzić, że między formą użytkowania a wielkością i szybkością respiracji glebowej zaznacza się pewna zależność. Dodatkowo uzyskane wyniki dały podstawy do stwierdzenia, że osiedla domków jednorodzinnych nie wykazują tak dużej antropopresji na środowisko glebowe, jak mogłoby się wydawać.

Slowa kluczowe: aktywność mikrobiologiczna gleb, inżynieria środowiska, metoda indukowanej substratem respiracji (SIR), użytkowanie terenu, właściwości gleb 